\title{
Social Mobilization in Simeulue Coastal Community Education
}

\author{
Arfriani Maifizar*, Sopar, Damrus, Sutikno, Nila Trisna, Yulina Astuti, \\ Ayu Citra Santyaningtyas, Irsadi Aristora
}

Faculty of Social Science and Political Science, Universitas Teuku Umar, Aceh, Indonesia

*Corresponding author email: arfrianimaifizar@utu.ac.id

\begin{abstract}
The title of this research is "Social Mobilization in Simeulue Coastal Community Education." The research site which was the location for data collection was Gampong Babul Makmur, Simeulue Bara District, Simeulue District, Aceh Province. This research raised the problem of how the community's perception of social mobilization in education in coastal communities in Babul Makmur village, West Simeulue District. The research objective was to determine people's perceptions of social mobilization in education in coastal communities in Gampong Babul Makmur, West Simeulue District. The research used a qualitative method with interview instruments conducted on several community leaders. The results of the research concluded that the Baitul Makmur village community had a perception of education as a means of social mobility to obtain a better or higher status. Higher education is important to expand mobility to improve social status. The community believes that having a tertiary education with a college diploma will make it easier to get a job.
\end{abstract}

Keywords: Social Mobility, Education, higher education

\section{INTRODUCTION}

The people of Simeulue are archipelago people who have their source of life from marine products and live in coastal areas and lowlands. The people of Simeulue are generally descended from the Devayan ethnic group. Based on the geography of the island of Simeulue, the people of Simeulue live in an archipelago with the island of Simeulue being the largest. Their daily interactions use the dominant language used, namely Sigulai. In terms of kinship, the people of Simeulue recognize the nuclear family as the most basic and strong kinship. While their broader kinship also recognizes the community called kampong led by a village head called Datuk now known as the keuchik, but for other traditional leaders they recognize the imum meunasah, and tuha peut as traditional traditional institutions.

The people of Simeulue are gradually developing, marked by rapid interaction with other regions. One of the signs of community development is the human resources who have received a lot of formal and non-formal education. They assume that if they do not make changes that are driven by the spirit of change from within, they will continue to be left behind, it is said that they live in a geographic archipelago far from the crowds and advances in science and technology. Encouragement in the people of Simeulue through education has brought broad changes to everyday social mobility. Related to social mobility or group movement on a large scale, which is marked by the ups and downs of social status between rich and poor, farmers and entrepreneurs or other measures used, such as property ownership, position and other social status. According to Ranjabar [1], it explains that social mobility, both horizontal and vertical, allows people to change status, for example a change in their social status in society.

This phenomenon in the village can be explained by experiencing rapid social mobility as indicated by the number of ages of children who continue formal education or attend semankin high school or dayah education. The assumption of education villagers is that they can change quickly, be it a change in mindset or a change in social 
status. Therefore, through good education, their social status will be good or the higher their education, the higher their mastery of knowledge will be. The level of education that is increasingly high in the life of the Simeulue people in the village is needed as a capital to develop themselves in finding work both in government and private institutions or to open business opportunities. The job and effort that is expected really requires expertise or skills that are based on knowledge. Mahmud and Suntana [2] explain that science is a struggle for life, which includes extreme competition. The survival of life in competition will not be achieved by those who are shy or weak.

Regarding the background, the researcher interested in obtaining accurate information behind social mobility in education for the life of the Simeulue people, especially in Gampong Babul Makmur, West Simeulue District who live on the coast of the island of Simeulue by formulating the title Social Mobilization in Simeulue Coastal Community Education. This study uses qualitative methods, namely research based on an investigation of a social problem that produces oral explanations [3]-[5]. While the purpose of this study is to describe the community's perception of social mobility in education in the coastal communities of Simeulue in Gampong Babul Makmur and to determine social mobility in education in coastal communities of Simeulue village of Babul Makmur.

\section{LITERATURE REVIEW}

\subsection{Social Mobility}

Young and Mack in Soekanto [6] explained that social mobility is a movement in a social structure. The social structure includes the characteristics of the relationship between individuals in the group and the relationship between individuals and the group. Because social mobility is a movement in the social structure, movements that occur can be carried out between individuals and groups between social groups. Meanwhile, Giddens asserts that the process of social movement in individuals or social groups occurs from a position that is not good to good or from a position below to a position above. So it can be concluded that social mobility is the social movement of a person or group of people from one position to another which is different and increases higher [7]-[10].

\subsection{Education in Sociological Analysis}

Tilaar explained that the sociological view of the importance of education is a necessity for people's lives. This means that education in sociological analysis is a community need not only an individual need. It can be further explained that sociologically, community education is a focus based on human interaction, interaction between groups and interactions between humans and groups in the process of community life. This interaction then affects each other involving elements that are good or true or the opposite can also occur. In the process of interaction that involves humans, especially children, adolescents and adults, it can be done through the educational process in its socialization. As members of the community, children are students who receive education or learning through their daily interactions either through their parents, family, friends and play groups as well as formal or non-formal educational institutions.

In certain conditions, the first environment related to family education is the parents of the mother and the father at home, other close relatives in the house. The parties who play a role can be referred to as social environments. Soekanto [6] explains that the socialization process of education which is focused on the individual human generally has parties who can play a role. Those environments that play an important role in the continuity of the education of children or humans in general include a) parents, siblings and close relatives b) play groups c) educator groups (schools). Education in sosilogical analysis can also be interpreted as a process to develop the values or existence of students or human beings who are social, cultured in an order of life with local, national and global dimensions. Education by the community is used to support the growth of students to gain the ability and habits of good thinking to solve problems in life.

\subsection{Educational Review of Stratification and Social Mobility}

Mahmud and Suntana [2] explained that education is a universal element of culture that grows and develops in society, the specific nature of cultural universals differs between communities. In general, there are several types of education that are known in the community, namely: a) practical skills education, b) status group membership education and c) bureaucratic education. Practical skills education is designed to provide certain technical skills and abilities, which are considered important in carrying out other work activities. This education is based on a teacher-apprenticeship teaching form. Status group education is carried out for symbolic purposes and to strengthen the prestige and privileges of elite groups in society. In general this education is used for knowledge and discussion of esotric knowledge bodies. Meanwhile, bureaucratic education is common in various major civilizations, especially those that have a centralized bureaucracy. In general, education recognizes the tripentral education environment, namely formal education, informal environment, and non-formal education. The three educational environments work together in an effort to strengthen the universal social system.

If the school education institutions no longer keep up with the changes that have occurred, their function will be lost and the community will leave. Therefore, the social function of schools as educational institutions in developing human potential is still important for the continuity of social dynamics towards ideal ideals, namely an equilibrium society [11]. Educational institutions based 
on the needs of the community will be able to grow and develop according to existing progress. Therefore, society should be a determining factor in the progress and development of schools as educational institutions that will educate children's potential, because children can also learn in community life. Meanwhile, the government is also responsible for the continuity of educational development for the availability of learning opportunities in people's lives [12]-[13].

\subsection{The Relevancies Between Education and Social Mobility}

The relevancies between education and social mobility is seen as a means of obtaining a better social status in society. The better the level of education a person has, the more hopeful there will be for social mobility in life. Education is seen as an expectation of being able to move from the lower class to the higher class. Education as an open means of social mobility can be passed by every member of society regardless of status or previous descent. Whereas in the former society it was the descendants who determined a person's social status above or below which was difficult to penetrate because of the strict system. The difference in social class in essence can be reduced even though it cannot be completely eliminated. In reality, these ideals are not easily realized. However, it needs to be underlined that a good education for everyone will have a direct influence on the development and progress of themselves and their lives [14]-[16].

\section{RESULT AND DISCUSSION}

When viewed through the education aspect of the Gampong Babul Makmur community, West Simeulue Subdistrict in general has developed in the field of education, this condition can be seen from the willingness to continue education in schools from low education to higher education. Results of interviews with Noni Purwanti about the willingness to continue education and the level of education of the Gampong Babul Makmur community, West Simeulue District can be explained that the willingness of the community to enter formal education institutions from primary to tertiary education is very good, as if they are competing to be able to continue education which has become a necessity of life to be able to change their lives. The current level of education greatly affects a person in determining job acquisition and position, people with low education will only fill low positions and people with higher education are likely to get better jobs and positions. An adequate level of education is important for entry requirements into the world of work, because through education it is proven by a certificate as legality that it will be easy to get a decent job and vice versa. Furthermore, it was explained again that through education one can increase status in society both in employment status, position and social status in society.
Higher education is necessary at least to be able to get a decent job for him because nowadays a diploma is still an important requirement even though this certificate is not a guarantee for someone to get a certain job. Although, the higher a person's education, the greater the hope of getting a good job or ensuring the fulfillment of primary or secondary needs. This is as explained by Marzali [17], that the problems in front of the eyes of students who continue their higher education are mainly stomach problems, career problems, future problems and so on. Through education, people from lower classes can advance to higher classes. This is stated by one of the people that in this day and age a public-school graduate like me is no longer meaningful in improving social status, but an academic degree will be very helpful in achieving an important place in the world of work, because those who are already high higher education as an absolute requirement to maintain social status. The results of the interview can be explained that thanks to education that improves his social status, one of the heads of the family revealed that he used to be underprivileged people, my father died when I was in elementary school (SD), my mother worked washing clothes at a neighbor's house but her wish was very strong. strong to send me to school. When my Senior High School (SMA) worked to clean up the school near where we lived, I saved my work so I could enter college, I went to college while working as a janitor on the campus where I studied, I didn't feel ashamed of my determination. must be successful until obtaining a bachelor's degree.

Provision of undergraduate or undergraduate education has made it easier for me to get a job and changed my family's social status to be better than the previous status. The perception of the people of Gampong Babul Makmur, West Simeulue District can be concluded that education is a way for social mobility. Education is seen as a way to achieve a better position in society. This was stated by the head of the village/Keuchik Gampong Babul Makmur, West Simeulue Subdistrict, the high enthusiasm of the community in improving social status through education was very clear in the last five years. which requires a minimum education level of high school and undergraduate graduates. The high level of education has a great opportunity to increase social status, the higher the level of education, the greater the chance of a person's mobility. Elementary and even high school education has almost no effect on social mobility. To become an office boy, you have to apply with a high school diploma. However, if the obligation to study is increased to high school, then a high school certificate will have no meaning in seeking a high position or moving to a higher position. Higher education is now considered a condition for social mobility. Now even for college graduates, it is now difficult to get a high position. This was reaffirmed by Mr. Herman as Keuchik that today, let alone a high school diploma that has a university diploma currently finds it difficult to get a job, everywhere higher education has become an entry requirement for work both in government institutions and in private institutions. 


\subsection{Public Perception of the Education Level of Babul Makmur Village}

The mobility of the Gampong community's education regarding the perception of the level of education in Gampong Babul Makmur, West Simeulue District, almost in general the community has the perception that one's education is a mobility ladder for status in society. Education is the most important thing in many worlds of work, because without a higher education certificate, you can get a decent job in the social structure of society. The results of the interview explained that the more education a person receives, the better because education can form a more advanced mindset because he acquires various kinds of knowledge, can get a job with his knowledge, which will certainly raise one's status in society.

The view of the wider community having a higher education certificate is evidence of his ability to complete education that is impossible for people with low abilities. People who have gone to school have basic skills at least good at reading and arithmetic which are needed in the life of society in today's era. Furthermore, he can broaden his views and understanding of world problems. This is because tertiary institutions can still provide expansion of social mobility, even though the guarantee of a diploma does not necessarily increase for social status. Schools are also seen as avenues for social mobility. Through educational institutions, people from lower classes can advance to higher status. Nowadays, graduating from Elementary School (SD), Junior High School (SMP) and equivalent and Senior High School (SMA) is no longer meaningful in improving social status, but an academic degree will greatly assist in the achievement of occupying an important place in the world of work. Because those who are already in high position see higher education as an absolute requirement to maintain their social status, I can see this for myself as an example in my own person. Along with the development of the world of education and changes in the pattern of human life, then the community has more confidence in the ability or practical individual skills obtained from educational institutions as evidenced by graduates with a certificate. This is what ultimately provides opportunities and encouragement for the growth of social mobility that can provide an individual with skills needed by the world of work which certainly affects the achievement of social status.

From the intellectual point of view, educated people have higher social status, the higher the school level, the higher the level of mastery of knowledge so that they are considered to have a high status in society, just as universities can still provide an expansion of mobility, although the guarantee of a diploma does not necessarily increase for social status. Schools are also seen as avenues for social mobility. Through education, people from lower classes can advance to higher status groups. A society with an open stratification system has a greater level of mobility compared to a society with a closed social stratification system. If the level of mobility is high, even though the social backgrounds of individuals are different, then the community can still feel that they have the same rights in achieving a higher social position. If the level of social mobility is low, then of course most people will be trapped in a low status.

The perception of the Babul Makmur village community that education is a path to social mobility. Education is seen as a means to gain a better position in society. The high enthusiasm of the community in improving social status through education has been very clearly seen in the last five years, of which only a few were aware that the importance of education is now increasing in attending school, this is due to job application requirements that require a higher level of education and ability in accordance with qualifications education

\subsection{Mobility of Community Education in Gampong Babul Makmur}

The relationship between humans and education is very close, in the broadest sense of education, namely all life situations that affect individual growth. Education is the source of social mobility in human life. Through human education can develop, education has a strategic function, namely to actualize human potential. In his life, humans are driven partly by the need to achieve something and partly by social responsibility in society. Education also greatly influences a person in his life in the midst of society, such as increasing social status so that education is able to provide a change that is deeply felt by educated youth in village camps as revealed by one of the following informants. This is like the results of the interview that there are some people who have advanced thinking, those who are educated, are often used for every village development activity, those who are educated are always in control because they know every task that is given. The people in Gampong Babul Makmur really respect and value those who are educated. Furthermore, it was reaffirmed that education is very important in life, with education for someone who is easy to get a job, is often involved in village development, besides that education has changed the social status in society from low status to high status. People who have high education get the trust of the community to take office, so that people respect and appreciate highly educated people.

The benefits of education that each person has are different - the most obvious difference is that every society has characteristics so that each of these characteristics must be understood so that people can achieve benefits in their education. In addition, the influence of other people in society can affect the education of the community itself, either directly or indirectly. The benefits that will be obtained by an educated community are easy for an educated community to find it easier to get a job in a position, in government offices or in private companies. Quality human beings are produced from a good process, one of these processes is education. Education is one of the needs that is upheld in the present. Without education, humans will be left behind and will limit their space to move. 
The benefits of education that each person has are different - the most obvious difference is that every society has characteristics so that each of these characteristics must be understood so that people can achieve benefits in their education. In addition, the influence of other people in society can affect the education of the community itself, either directly or indirectly. The benefits that will be obtained by an educated community are easy for an educated community to find it easier to get a job in a position, in government offices or in private companies. Quality human beings are produced from a good process, one of these processes is education. Education is one of the needs that is upheld in the present. Without education, humans will be left behind and will limit their space to move.

Meeting this need is done in order to sustain life. This is because living humans need food, shelter, clothing, and other necessities. Everyone certainly has a purpose in life, a better life goal that is pursued in various ways. The way that is done by a person is varied and has various factors that make a person achieve something such as receiving a higher education experienced by the Babul Makmur village community. The driving factor for the Gampong Babul Makmur community according to the results of the interview explained that in improving their education the community wanted to get a good job too, jobs that were obtained by educated people were not just obtained, jobs that were obtained were due to high educational factors and proven by a diploma from college. Higher education and the goal of changing people's lives are even better able to make their lives more prosperous.

\section{CONCLUSION}

Based on the results of the analysis carried out on social mobility in the education of the Gampong Babul Makmur community, West Simeulue District. 1) Education is seen as a means of social mobility to obtain a better or higher status. 2) Higher education is important to expand mobility to increase social status. 3) The community believes that having a tertiary education with a university diploma will make it easier to get a job.

\section{REFERENCES}

[1] J. Ranjabar, Perubahan Sosial Dalam Teori Makro. Bandung: Alfabeta, 2008.

[2] Mahmud, I. Suntana, Antropologi Pendidikan. Bandung: Pustaka Setia, 2012.

[3] F. Hanurawan, Qualitative Research in Psychology. Journal of Educational, Health and Community Psychology, 1 (2) (2012), 120-132.

[4] E. Daniel, The Usefulness of Qualitative and Quantitative Approaches and Methods in Researching Problem-Solving Ability in Science Education Curriculum. Journal of Education and Practice, 7 (15) (2016), 91-100.
[5] H. K. Mohajan, Qualitative Research Methodology in Social Sciences and Related Subjects. Journal of Economic Development, Environment and People, 7 (1) (2018), 23-48.

[6] S. Soekanto, Sosiologi Suatu Pengantar. Bandung: Rajagrafindo Persada, 2006.

[7] J. Goldthorpe, Understanding - and Misunderstanding - Social Mobility in Britain: The Entry of the Economists, the Confusion of Politicians and the Limits of Educational Policy. Journal of Social Policy, 42 (3) (2013), 431-450.

[8] H. Rolfe, Inequality, Social Mobility and the New Economy: Introduction. National Institute Economic Review, 240 (2017), R1-4.

[9] N. A. Paramitha, S. Supriyadi, A. Zuber, The Importance of Educational Level for Farmer's Upward Social Mobility in Wringinpitu Village. International Journal of Pedagogy and Teacher Education, 2 (2018), 171-182

[10] K. Hoskins, B. Barker, Social mobility: The potential of a genealogical approach. British Educational Research Journal, 45 (2) (2019), 238-253.

[11] H. A. R. Tilaar, Pendidikan, Kebudayaan, dan Masyarakat Madani Indonesia, Cetakan III. Bandung: Remaja Rosda Karya, 2002.

[12] C. J. Gil-Hernández, I. Marqués-Perales, S Fachelli, Intergenerational social mobility in Spain between 1956 and 2011: The role of educational expansion and economic modernisation in a late industrialised country. Research in Social Stratification and Mobility, 51 (2017), 14-27.

[13] S. Budiati, S. Rochmat, The Impact of Education on Social Stratification and Social Mobility in Communities in Indonesia. Proceedings of the 2nd International Conference on Social Science and Character Educations (ICoSSCE 2019), Advances in Social Science, Education and Humanities Research, 398 (2020), 75-78

[14] L. Hao, S. Pong, The Role of School in the Upward Mobility of Disadvantaged Immigrants' Children. Ann Am Acad Pol Soc Sci., 620 (2008), 6289.

[15] N. Yusuf, Impact of Education on Social Mobility among Residents in Ilorin Metropolis. An International Multi-Disciplinary Journal, 3 (1) (2009), 373-387.

[16] P. Brown, D. Reay, C. Vincent, Education and social mobility, British Journal of Sociology of Education, 34 (5-6) (2013), 637-643.

[17] A. Marzali, Antropologi dan Pembangunan Indonesia. Jakarta: Kencana, 2007. 